might not be noticed in the field in the absence of an adjacent control.

We thank Professor A. J. Rutter for the use of facilities.

Department of Botany,

J. N. B. BeLL

Imperial College Field Station,

Silwood Park,

Ascot

Health Physics and Medical Division,

AERE Harwell

Received July 17; revised July 26, 1972.

1 Bleasdale, J. K. A., thesis, University of Manchester (1952).

2 Meetham, A. R., Atmospheric Pollution, 178 (Macmillan, New York).

3 The Investigation of Air Pollution, National Survey Annual Summary (Warren Spring Laboratory).

\section{Crystallization in vivo of Rhabdophane in Human Lungs}

We have observed an unusual accumulation of inorganic rod-like particles with a mean diameter of about $10 \mathrm{~nm}$ in the lungs of two reproduction photographers (Fig. 1). From the electron diffraction of the particles the $d$-spacings were calculated (Table 1).

The X-ray powder diffraction pattern of the isolated lung dust does not show any additional lines except those of quartz which can be traced in every human lung. A semiquantitative $\mathrm{X}$-ray fluorescence analysis showed the presence of the following elements (in order of decreasing frequency): cerium, lanthanum, calcium, neodymium, thorium, praseodymium, yttrium and samarium. In addition; silicon, iron and potassium, which are common in lung tissue, were also detected. Peaks at $1,060 \mathrm{~cm}^{-1}, 623 \mathrm{~cm}^{-1}$ and $540 \mathrm{~cm}^{-1}$ in the infrared spectrum indicate that the rare earth elements are combined with phosphate ions.

These results leave no doubt that the particles consist of rhabdophane, ( $\mathrm{La}, \mathrm{Ce}, \mathrm{Nd}$. . .) $\mathrm{PO}_{4} \cdot \mathrm{H}_{2} \mathrm{O}$, or at least partly of the rather rare thorium-rich variety brockite. The analysis of the elements contained in the ash of a arc-lamp electrode which had been used in the workshop where both photographers

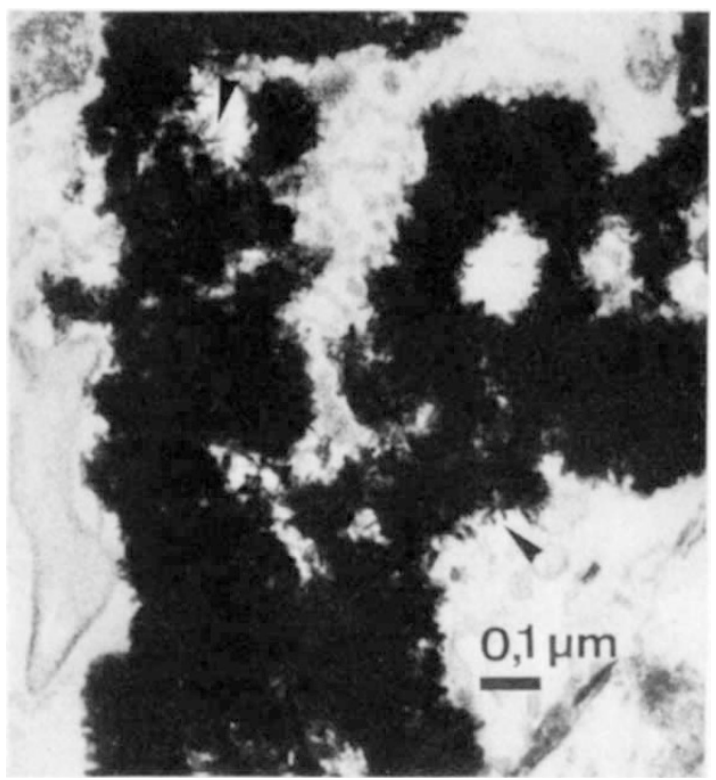

Fig. 1 Electron micrograph of lung tissue: detail of a rhabdophane containing cellular inclusion body.

\begin{tabular}{|c|c|c|c|c|c|c|}
\hline \multirow{3}{*}{\multicolumn{2}{|c|}{$\begin{array}{l}\text { Table } 1 \text { Electro } \\
\text { Lung dust } \\
d(\AA) \quad I / I_{0}\end{array}$}} & \multicolumn{5}{|c|}{$\begin{array}{l}\text { Diffraction Pattern of Lung Dust and } d \text {-Spacings } \\
\text { Rhabdophane and Brockite }\end{array}$} \\
\hline & & \multicolumn{2}{|c|}{$\begin{array}{l}\text { Rhabdophane } \\
\text { (ASTM 12-277) }\end{array}$} & \multicolumn{3}{|c|}{$\begin{array}{c}\text { Brockite } \\
\text { (ASTM 15-248) }\end{array}$} \\
\hline & & $d(\AA)$ & & $d(\AA)$ & $I / I_{0}$ & $h k l$ \\
\hline $\begin{array}{l}6.08 \\
4.39 \\
3.53 \\
3.04 \\
2.82 \\
2.36 \\
2.12 \\
1.93 \\
1.86\end{array}$ & $\begin{array}{r}30 \\
60 \\
50 \\
90 \\
100 \\
20 \\
40 \\
20 \\
40\end{array}$ & $\begin{array}{l}6.07 \\
4.40 \\
3.49 \\
3.02 \\
2.83 \\
2.36 \\
2.15 \\
1.92 \\
1.859\end{array}$ & $\begin{array}{r}60 \\
80 \\
60 \\
100 \\
80 \\
40 \\
80 \\
40 \\
60\end{array}$ & $\begin{array}{l}6.06 \\
4.37 \\
3.47 \\
3.03 \\
2.83 \\
2.37 \\
2.15 \\
1.92 \\
1.86\end{array}$ & $\begin{array}{r}40 \\
70 \\
50 \\
100 \\
70 \\
30 \\
70 \\
30 \\
50\end{array}$ & $\begin{array}{l}100 \\
101 \\
110 \\
200 \\
102 \\
112 \\
211 \\
301 \\
212\end{array}$ \\
\hline \multicolumn{2}{|c|}{ Hexagonal } & \multicolumn{2}{|c|}{ Hexagonal } & \multicolumn{3}{|c|}{ Hexagonal } \\
\hline \multicolumn{2}{|c|}{$\begin{array}{l}\mathrm{a}_{0}=7.02 \\
\mathrm{c}_{0}=6.35_{5}\end{array}$} & \multicolumn{2}{|c|}{$\begin{array}{l}\mathrm{a}_{0}=6.98 \\
\mathrm{c}_{0}=6.39\end{array}$} & \multicolumn{3}{|c|}{$\begin{array}{l}a_{0}=6.98 \\
c_{0}=6.40\end{array}$} \\
\hline
\end{tabular}

had worked showed a pattern similar to the lung dust with respect to the rare earth elements. X-ray powder diffraction analysis revealed, however, that in the ash these elements were present as oxides. Therefore, it must be concluded that the inhaled oxides were gradually converted to rhabdophane (or brockite) within the lung tissue. To our knowledge the in vivo crystallization of these rare minerals has not been previously observed.

Institute of Agricultural Chemistry,

H. STICHER

Swiss Federal Institute of Technology, Zürich

Institute of Pathological Anatomy,

M. A. SPYCHER

J. R. RUETTNER

University of Zürich

\section{Dimethylnitrosamine in the Human Vaginal Vault}

THE high frequency of cancer of the uterine cervix in southern Africans $^{1}$ and the general epidemiological features of the disease suggest that chemical carcinogens might be found in infected discharge from the human cervix.

Pathological cervical and vaginal discharges contain cellular matter in various stages of degradation in a "protected" environment at $p \mathrm{H}$ (about 5.5), and temperature favourable for chemical change. Discharges are usually infected with a wide variety of microorganisms, often including Trichomonas, Monilia and E. coli. Nitrosamines, well known potent carcinogens ${ }^{3}$, might be synthesized by such organisms or formed when and where amines and nitrites (or possibly nitrates in reducing conditions) are present.

Samples were prepared and dimethylnitrosamine isolated by the technique of Nunn and Du Plessis ${ }^{4}$. Isolation and identification of nitrosamines in biological samples (especially when present in the p.p.b. range), based on final gas chromatographmass spectrometry, are the most reliable (L.S. Du P. and J.R.N., in preparation). Our identification of dimethylnitrosamine was based both on gas chromatography (where a peak coincided with that of dimethylnitrosamine under two different sets of conditions) and on the mass spectrum of the component responsible for this peak. This spectrum displayed distinctive peaks at mass 74 (parent ion of dimethylnitrosamine) and at mass 30 , which could only have been due to $\mathrm{NO}^{+}$, characteristic of nitrosamines. Although the increased intensity of mass 30 could have been due to an ion such as ${ }^{15} \mathrm{~N}_{2}{ }^{+}$, it is extremely unlikely here.

A detailed examination was made of pooled discharges taken from 100 African patients attending an antenatal clinic in Johannesburg. Specimens were collected at random, the criterion of choice being only the availability of material. Most patients in this first series were pregnant, because the 